\title{
PENGGUNAAN MODEL PEMBELAJARAN INTERAKTIF BERBASIS AKTIVITAS UNTUK MENINGKATKAN PRESTASI BELAJAR SISWA KELAS VI PADA PELAJARAN PKN SD NEGERI 09 KABAWETAN
}

\author{
Elfa Sumiyati, S.Pd.SD \\ SD Negeri 05 Kabawetan, Kepahiang \\ 085268229835
}

\begin{abstract}
Abstrak
Dengan menggunakan model pembelajaran interaktif berbasis aktivitas siswa lebih aktif karena suasana belajar mengarah kepada siswa menemukan hasil pemahaman melalui suatu interaksi, mudah dalam memahami materi ajar, karena dibantu melalui media belajar yang kongkrit.Dari tindakantindakan yang dilaksanakan dalam penelitian ini, ada peningkatan prestasi belajar siswa secara signifikan dari pra siklus, siklus 1 ke siklus 2 dengan rata-rata nilai yang diperoleh : pada pra siklus dari 16 siswa prestasi belajar siswa mengalami peningkatan belajar dari pra siklus, siklus 1 ke siklus 2 dengan rata-rata nilai yang diperoleh : pada pra siklus dari 16 siswa, dengan nilai rata-rata 66,25 pada pra siklus yang tuntas belajar hanya 56,25\% atau 9 anak, sedangkan siswa yang tidak berhasil 44,75 atau 7 anak. Pada siklus 1 nilai rata-rata 68,75 meningkat yaitu siswa yang tuntas dalam belajar $62,50 \%$ atau 10 anak sedangakan yang belum tuntas 33,50\% atau 6 anak. Pada siklus 2 ada kenaikan yang cukup signifikan yaitu rata-rata nilai menjadi 75 sesuai dengan yang diharapkan, dengan hasil ketuntasan belajar mencapai $87,50 \%$ atau 14 anak sedangkan yang belum tuntas $12,50 \%$ atau 2 anak.hal ini menjadi perhatian bagi peneliti untuk membibing supaya dapat tuntas seperti temantemanya.Hasil penelitian membuktikan bahwa penerapan pembelajaran menggunakan model pembelajaran interaktif berbasis aktivitas dapat meningkatkan prestasi belajar dan pemahaman konsep bagi siswa PKN pada kelas VI SD Negeri 09 Kabawetan Kecamatan Kabawetan Kabupaten Kepahiang, Provinsi Bengkulu.
\end{abstract}

Kata Kunci: Interaktif, aktivitas prestasi, signifikan, siklus

\section{PENDAHULUAN}

Dalam proses mengajar guru menjadi pemeran utama dalam menciptakan situasi interaktif yang edukatif, yakni interaksi antara guru dengan siswa, siswa dengan siswa dan dengan sumber pembelajaran dalam menunjang tercapainya tujuan belajar. Untuk terwujudnya proses belajar mengajar seperti itu sudah tentu menuntut upaya guru untuk mengaktualisasikan kompetensinya secara profesional, utamanya aspek metodologis.

PKn sebagai salah satu bidang studi yang memiliki tujuan membekali siswa untuk mengembangkan penalarannya disamping aspek nilai dan moral, banyak memuat materi sosial bersifat hapalan sehingga pengetahuan dan informasi yang diterima siswa sebatas produk hapalan. Sifat pelajaran PKn tersebut membawa konsekuensi terhadap proses belajar mengajar yang didominasi oleh pendekatan ekspositoris, terutama guru menggunakan metode ceramah sedangkan siswa kurang terlibat atau cenderung pasif. Dalam metode ceramah terjadi dialog imperaktif. Padahal, dalam proses belajar mengajar keterlibatan siswa harus secara totalitas, artinya melibatkan pikiran, penglihatan, 
pendengaran, dan psikomotorik (ketrampilan, salah satunya sambil menulis). Jadi, dalam proses belajar mengajar, seorang guru harus mengajak siswa untuk mendengarkan, menyajikan media yang dapat dilihat, memberi kesempatan untuk menulis dan mengajukan pertanyaan atau tanggapan sehingga terjadi dialog, kreatif yang menunjukkan proses belajar mengajar yang intraktif positif. Situasi belajar seperti ini dapat tercipta melalui penggunaan pendekatan partisipatoris.

Proses belajar mengajar mempunyai makna dan pengertian yang lebih luas dari pada pengertian mengajar, karena didalamnya tersirat satu kesatuan kegiatan yang tidak terpisahkan antara siswa yang belajar dengan guru yang mengajar, sehingga terjalin dalam bentuk interaksi edukatif. Peran guru dalam pembelajaran PKN mempunyai hubungan erat dengan cara mengaktifkan siswa dalam belajar, terutama dalam proses pengembangan keterampilannya, pengembangan keterampilan yang harus dimiliki siswa adalah keterampilan berpikir, keterampilan sosial dan keterampilan praktis. Keterampilan berpikir dikembangkan untuk melatih siswa berpikir logis dan sistematis melalui proses belajar mengajar dengan model pengembangan berpikir kritis, keterampilan sosial dan praktis melalui model dialog kreatif. Ketiga keterampilan tersebut dapat dikembangkan dalam situasi belajar mengajar yang teraktif antara guru dengan siswa dan siswa dengan siswa.

Permasalah yang muncul disekolah saat melaksanakan pembelajaran siswa dalam bidang PKN adalah kurangnya motivasi dari diri siswa dalam mengikuti proses belajar mengajar . mereka kurang serius dalam memfokuskan diri dalam mengikuti materi pembelajaran . Hal ini karena dalam pelaksanaan belajar mengajar guru lebih sering menggunakan buku sebagai sumber belajar, dimana guru hanya menggunakan metode ceramah saja dalam menyampaikan dan menjelaskan materi pembelajaran PKN. Tidak adanya media peraga atau contoh gambar yang merupakan sarana pengetahuan nyata bagi siswa.
Permasalahan yang dihadapi oleh siswa yaitu kurangnya motivasi dari diri siswa dalam mengikuti proses belajar mengajar beberapa masalah yang terjadi dalam proses belajar mengajar yaitu (1) kurangnya interaksi antara guru dan siswa; (2) penguasaan guru tentang metode pengajaran masih belum maksimal; (3) siswa cenderung pasif dan kurangnya motivasi siswa; (4) metode yang digunakan dalam mengajar belum bervariasi/ monoton; (5) siswa cenderung hanya menghafal bukan memahami materi pelajaran

Tujuan pembelajaran interaktif berbasis aktivitas adalah sebagai berikut (1) meningkatkan partisipasi aktif siswa dalam pembelajaran; (2) meningkatkan pemahaman sosial antara siswa dengan lingkungan sekitar; (3) mendorong siswa untuk dapat menemukan dan menyelidiki sendiri konsep yang dipeljari mudah di ingat dan tidak mudah dilupakan peserta didik; (4) membantu siswa membentuk cara kerja bersama yang efektif, saling membagi informasi, serta mendengar dan menggunakan ide-ide orang lain; dan (5) melatih siswa belajar berpikir analitis dan mencoba memecahkan masalah yang dihadapi sendiri.

Kegiatan pembelajaran interkatif berbasis aktivitas didasarkan pada beberapa prinsip anatara lain (1) somatis yaitu siswa mengalami aktivitas fisik yang memungkinkan siswa berinteraksi dengan orang lain secara berpasangan atau kelompok, dari satu tempat ke tempat lain baik didalam maupun diluar kelas; (2) auditory yaitu siswa dimungkinkan untuk mendengar secara aktif dari bernagai sumber informasi; (3) visual yaitu siswa dimungkinkan untuk melakukan pengamatan gambar atau lingkungan sekitar; (4) intelektual yaitu siswa dimungkinkan untuk melakukan proses tanya jawab terhadap lingkungan belajarnya.

Pembelajaran berbasis aktivitas memiliki karakteristik umum dalam pelaksanaan pembelajaran oleh guru baik dalam kelas maupun diluar kelas. Karakteristik pembelajaran interaktif berbasis aktivitas menurut permendikbud nomor 103 tahun 2014 bersifat (1) interaktif dan inspiratif; (2) menyenangkan, menantang, dan 
memotivasi siswa untuk berpartisipasi aktif; (3) kontekstual dan kolaboratif; (4) memberikan ruang yang cukup bagi prakarsa, kreativitas, dan kemandirian siswa; dan (5) sesuai dengan bakat, minat, kemampuan, dan perkembangan fisik serta psikologis siswa.

Dalam rangka meningkatkan kualitas proses belajar mengajar dan hasil pembelajaran PKN. Bagi Siswa (1) siswa aktif dalam kegiatan belajar, sebab ia berpikir dan menggunakan kemampuan untuk menemukan hasil akhir; (2) siswa memahami benar bahan pelajaran, sebab mengalami sindiri proses menemukannya; (3) siswa menemukan sendiri konsep, prinsip atau teori yang dapat menimbulkan rasa puas; (4) siswa memperoleh pengetahuan dengan metode penemuan akan lebih mampu mentranfer pengetahuannya kepada berbagai konteks; (5) melatih siswa untuk lebih banyak belajar mandiri dan bertanggung jawab.

Pembelajaran adalah proses interaksi anatara siswa, antara siswa dengan guru dan sumber belajar pada suatu lingkungan belajar. Didalam pembelajaran, siswa didorong untuk menemukan sendiri dan mentransformasikan informasi kompleks, mengecek informasi baru dengan yang sudah ada dalam ingatannya. Dan mengembangkannya menjadi informsi atau kemampuan yang sesuai dengan lingkungannya. Pembelajaran menganut pandangan dasar bahwa pengetahuan tidak dapat dipindahkan begitu saja dari guru kepada siswa. Siswa adalah subjek yang memiliki kemampuan untuk secara aktif mencar, mengolah, mengkonstruksi, dan menggunakan pengetahuan untuk mengatasi masalah. Untuk itu pembelajaran harus berkenaan dengan kesempatan yang diberikan kepada peserta didik untuk mengkonstruksikan pengetahuan dalam proses kognitifnya secara utuh.

Motode pembelajaran interaktif berbasis aktivitas sering dikenal dengan nama pendekatan pertanyaan anak. Motode ini dirancang agar siswa akan bertanya dan kemudian menemukan jawaban pertanyaan mereka sendiri.

Pengembangan model pembelajaran interaktif berbasis aktivitas dalam PKN dapat dilakukan oleh guru pada semua pokok bahasan, dengan syarat harus memperhatikan sembilan hal.

\section{Faktor Minat dan Perhatian}

Kondisi belajar mengajar yang interaktif adalah adanya minat dan perhatian siswa dalam belajar, yang merupakan faktor utama penentu keaktifan siswa. Menurut Mursell terdapat 22 macam minat yang berguna bagi guru dalam memberikan pelajaran kepada siswa, diantaranya anak memiliki minat terhadap belajar dan guru berusaha membangkitkan minat siswa tersebut dengan cara memilih dan menentukan bahan pengajaran sebagai key concept untuk menciptakan perhatian siswa secara penuh. Upaya memusatkan perhatian siswa dapat dilakukan dengan cara mengajukan masalah.

\section{Faktor Motivasi}

Motivasi adalah suatu proses untuk menggaitkan motif-motif menjadi perbuatan guna mencapai tujuan, atau keadaan dan kesiapan dalam diri seseorang yang mendorong tingkah lakunya untuk berbuat sesuatu dalam mencapai tujuan tertentu. Sedangkan motif adalah daya dalam diri seseorang yang mendorongnya untuk melakukan sesuatu. Motivasi belajar dapat timbul dari dalam diri siswa ( motivasi intrinsic) dan pengaruh dari luar dirinya ( motivasi ekstrinsik). Dalam konteks ini guru berperan sebagai motivator untuk menumbuhkan kedua motivasi tersebut agar siswa dengan adanya potensi rasa ingin tahu ( sense of curiosity), rasa ingin maju dan lain-lain. Sedangkan motivasi eksterinsik dapat timbul dari upaya guru melalui penerapan ganjaran dan penghargaan atau reward serta hukuman atau punishment ( model S-R ), yang diorentasikan pada upaya memotivasi siswa untuk belajar.

\section{Faktor Latar Atau Konteks}

Belajar berdasarkan realita akan menarik, belajar dimulai dari yang sederhana dapat memotivasi siswa dan belajar berdasarkan pengalaman dapat mengikutsertakan siswa 
didalamnya. Dalam proses belajar mengajar, guru perlu mencari tahu pengetahuan, ketrampilan dan sikap yang telah dimiliki oleh siswa sehingga tidak terjadi pengulangan materi atau contoh karena akan menimbulkan kebosanan bagi siswa. Guru dituntut untuk mengembangkan pengetahuan dan ketrampilan, dan sikap yang dimiliki siswa tersebut.

\section{Faktor Perbedaan Individu}

Pada hakekatnya siswa adalah individu yang unik yang memiliki karakteristik berbedabeda, baik kecerdasan, minat, bakat, sifat, kegemaran dan latar belakang, yang dapat mempengaruhi proses belajar mengajar. Mursell, mengemukakan perbedaan siswa secara vertikal dan secara kualitatif. Perbedaan vertikal, yaitu berkenaan dengan intelegensi umum dari siswa dan perbedaan kualitatif berkenaan dengan bakat dan minatnya. Mengingat adanya perbedaan tersebut, guru hendaknya menyadari dan memaklumi apabila ada siswa yang berhasil dengan baik, atau bahkan sebaliknya mengalami kesukaran memahami pelajaran. Dalam hal ini, guru harus tetap memperhatikan persamaan dan perbedaan siswa dengan cara mengoptimalkan pengembangan kemampuan mereka masingmasing. Salah satu cara yang dapat ditempuh adalah bantuan khusus atau menjadikan siswa saling membelajarkan, artinya siswa yang pandai membantu siswa yang belum memahami sehingga dengan adanya perbedaan tersebut, guru tidak harus mengajar secara individu.

\section{Faktor Sosialisasi}

Sosialisasi atau proses hubungan social, pada masa kanak-kanak sedang tumbh dan ditandai dengan keinginannya untuk selalu berusaha menjalin hubungan dengan teman-temannya. Tetapi ada suatu hal yang perlu mendapat perhatian guru ketika berlangsung proses belajar mengajar, yaitu mereka akan merefleksikan keinginan dengan cara mengobrol dengan temannya sehingga akan menimbulkan kegaduhan di dalam kelas dan kegiatan belajar menjadi tidak efektif.

\section{Faktor Belajar Sambil Bermain}

Bermain merupakan kebutuhan bagi setiap anak yang sehat, karena bermain merupakan keaktifan yang menimbulkan kegembiraan dan menyenangkan. Proses belajar mengajar yang dilakukan dalam suasana bermain akan mendorong siswa aktif belajar dan pengetahuan, ketrampilan, sikap dan daya fantasi anak akan berkembang.

\section{Faktor Belajar Sambil Bekerja}

Pentingnya aktivitas belajar siswa dalam proses belajar mengajar diungkapkan John Dewey melalui metode proyeknya dengan konsep learning by doing. Aktivitas yang dimaksud adalah aktivitas jasmaniah dan aktivitas mental, yang digolongkan ke dalam lima kelompok yaitu:

a. Aktivitas visual (Visual activities), seperti membaca, menulis, melakukan eksperimen dan diskusi.

b. Aktivitas lisan (Oral Activities), seperti bercerita, membaca sajak, tanya jawab dan diskusi.

c. Aktivitas Mendengarkan (Listening Activities), seperti mendengarkan penjelasan guru, mendengarkan ceramah dan pengarahan.

d. Aktivitas Gerak (Motor Activities), seperti simulasi, bermain peran, membuat peta atau tabel dn grafik.

e. Aktivtas Menulis (Writng Activties), seperti mengarang, membuat ringkasan, dan membuat makalah.

\section{Faktor Inkuiri}

Pada dasarnya siswa memiliki potensi berupa dorongan untuk mencari dan menemukan sendiri ( sense of inquiry), baik fakta maupun data atau informasi yang akan dikembangkannya dalam bentuk cerita atau menyampaikannya kepada siswa lain, setelah melalui proses pemahaman. Dengan demikian berilah kepada siswa untuk menemukan sendiri informasi yang ada kaitannya dengan materi pelajaran. Dalam 
konteks ini tugas guru adalah menyampaikan informasi mendasar dan memancing siswa untuk mencari informasi selanjutnya.

\section{Faktor memecahkan Masalah}

Setiap anak menyukai tantangan (sense of Chalanger), demikian pula halnya dengan siswa dalam belajar. Belajar yang memiliki tantangan yang sesuai dengan tingkat kemampuan siswa akan mendorong mereka untuk belajar. Sebaliknya tantangan yang beratkan akan mematahkan semangat dan membuat siswa tidak betah belajar. Dalam proses belajar mengajar, tantangan tersebut dapat diciptakan oleh guru dengan mengajukan situasi bermasalah agar siswa peka terhadap masalah .

Guru dalam proses belajar mengajar yang intraktif dapat mengembangkan teknik bertanya efektif atau melakukan dialog kreatif dengan mengajukan pertanyaan kepada siswa. Sifat pertanyaan dapat mengungkapkan sesuatu atau memiliki sifat inkuiri sehingga melalui pertanyaan yang diajukan, siswa dikembangkan kemampuannya kearah berpikir kreatif dalam menghadapi sesuatu. Beberapa komponen yang harus dikuasai oleh guru dalam menyampaikan pertanyaan yaitu :

a. Pertanyaan harus mudah dimengerti oleh siswa

b. Memberikan acuan

c. Memusatkan perhatian

d. Pemidahan giliran dan penyebaran

e. Pemberian waktu berpikir kepada siswa

f. Pemberian tuntunan

Sedangkan jenis pertanyaan untuk pengembangan model dialog kraetif ada enam jenis yaitu :

a. Pertanyaan mengingat

b. Pertanyaan mendeskripsikan

c. Pertanyaan menjelaskan

d. Pertanyaan sintesis

e. Pertanyaan menilai

f. Pertanyaan terbuka

Untuk meningkatkan interaktif berbasis aktivitas dalam proses belajar mengajar, guru hendaknya mengajukan pertanyaan dengan memberi kesempatan kepada siswa untuk mendiskusikan jawabannya dan menjadi dinding pemantul atas jawaban siswa.

Prestasi belajar siswa adalah hasil belajar yang dinyatakan dalam bentuk nilai atau dalam bentuk skor, setelah siswa mengikuti pelajaran. Sedangkan, sudjana ( 1990 ) mendifinisikan hasil belajar sebagai kemampuan yang dimiliki siswa, yang ditunjukkan melalui perubahan tingkah laku ( behavioral change), setelah ia mengalami pengalaman belajar. Wujud tingkah laku sebagai hasil belajar itu, misalnya dari tidak tahu menjadi tahu, dari tidak mengerti menjadi mengerti, atau dari tidak memahami menjadi paham.

Pembelajaran yang berhasil ditunjukkan oleh tercapainya hasil belajar yangoptimal. Wujud pencapaian hasil belajar siswa lazimnya dinyatakan dengan nilai prestasi belajar, salah satunya adalah nilai ulangan harian. Sesuai dengan nama atau istilahnya, nilai ini diperoleh siswa setelah pelaksanaan suatu ulangan harian.

\section{METODE}

\section{Siklus I}

\section{Perencanaan}

Rencana perbaikan pembelajaran yang peneliti susun antara lain meliputi:

mengadakan tanya jawab dan diskusi tentang kenampakan alam, sosial budaya negara-negara tetangga.

siswa berdiskusi dan melakukan tanya jawab tentang kenampakan alam dan sosial negaranegara tetangga.

\section{Pelaksanaan}

Adapun pelaksanaan dari rencana pembelajaran antara lain sebagai berikut :

Guru menjelaskan materi dengan melakukan tanya jawab dengan siswa membimbing siswa dalam mengerjakan LKS membahas LKS untuk mengukur kemampuan siswa dalam menerima pelajaran dari guru.

\section{Pengamatan}

Beberapa aspek yang diamati antara lain :

a. Menjelaskan konsep kenampakan alam 
b. Memimpin diskusi kelompok

c. Membimbing siswa diskusi

d. Menarik kesimpulan dari pelaksanaan diskusi

\section{d.Refleksi}

Kegiatan pada siklus I ini merupakan refleksi yang akan kami gunakan dalam melihat kekurangan dan kelebihan yang memungkin timbul pada perbaikan pembelajaran,

\section{HASIL}

Pada pra pembelajaran jumlah siswa yang tidak tuntas dalam mengikuti pembelajaran sangat tinggi. Setelah dilaksankan perbaikan pembelajaran pada siklus 1 nampak sekali peningkatan hasil belajar siswa yaitu sebesar $62,50 \%$ atau 10 siswa sudah tuntas dan 6 siswa belum tuntas. Pada siklus 2 mengalami peningkatan secara signifikan sebesar 87,50\%.

\section{PEMBAHASAN}

kami temukan beberapa kekuatan dan kelemahan pada diri peneliti. Dengan mengadakan perbaikan pembelajaran ini peniliti lebih rinci dalam melihat permasalahan yang sering timbul pada pembelajaran pada umumnya, maka peniliti juga bisa segara membuat rencana perbaikan yang bisa meminimalkan masalah yang ada.

Pada saat ini ternyata penelitian yang dilakukan oleh peniliti jarang tidak bisa diakui keabsahannya, karena penelitian ini dilakukan dalam skala yang sempit ( hanya pada kelompokkelompok tertentu

Penerapan Model Pembelajaran Interaktif berbasis aktivitas Untuk Meningkatkan Prestasi Belajar siswa. Sebelum mengajar atau pembelajaran dilaksankan, seorang guru harus membuat rencana pelaksanaan pembelajaran (RPP), menentukan konsep materi yang akan diajarkan kepada siswa, mencari dan merumuskan masalah yang sesuai dengan konsep tersebut, serta merencanakan strategi pembelajaran yang sesuai atau yang cocok.
Mengacu pada model yang digunakan, maka selama proses kegiatan belajar mengajar siswa dapat memusatkan perhatiannya pada pokok bahasan yang akan dijelaskan. Siswa memperoleh pengalaman yang dapat membentuk ingatan yang kuat, siswa terhindar dari kesalahan dalam mengambil suatu kesimpulan, pertanyaanpertanyaan yang timbul dapat dijawab sendiri oleh siswa pada saat dilaksanakannya evaluasi, apabila terjadi keraguan siswa dapat menanyakan secara langsung kepada guru, kesalahan yang terjadi dari hasil ceramah dapat diperbaiki karena langsung terjadi interaksi antara guru dan siswa dalam proses belajar mengajar.

Kesalahan yang terjadi dari hasil ceramah dapat diperbaiki dengan cara

1. Mengadakan dialog dengan siswa dan membahas tentang materi yang telah diajarkan namun belum banyak yang memahaminya

2. Memberikan tugas kelompok yang berupa lembar kerja kelompok, sehingga peneliti dapat mengukur kemampuan siswa dalam memahami pembelajaran.

3. Menggunakan metode pembelajaran yang bervariasi yaitu metode ceramah, metode tanya jawab, presentasi dan pemberian tugas secara kelompok.

Adapun tahapan-tahapan perencanaan perbaikan pembelajaran sebagai berikut :

1. Membuat rencana perbaikan pembelajaran secara tertulis yang berisi langkah-langkah pelaksanaan pembelajaran yang sekiranya siswa dapat dengan mudah mengikuti pembelajaran.

2. Menyiapkan lembar observasi yang merupakan hasil kesepakatan antara peneliti dengan teman sejawat yang bertindak sebagai selaku pengamat.

3. Membuat lembar kerja kelompok untuk mengetahui tingkat keberhasilan pembelajaran siswa.

4. Mendeskripsikan nilai-nilai juang dalam perumusan pancasila dengan kalimat runtut

5. -Mengadakan tanya jawab mengenai hal-hal yang berhubungan dengan materi.

6. Siswa mengerjakan soal postes. 
7. Secara bersama-sama siswa membuat kesimpulan hasil belajar.

Beberapa aspek yang diamati antara lain, sebagai berikut :

1. Menjelaskan konsep kenampakan alam

2. Memimpin diskusi kelompok

3. Membimbing siswa berdiskusi

4. Menarik kesimpulan

\section{KESIMPULAN}

Berdasarkan uraian pembahasan dan hasil penelitian diatas mulai siklus 1 sampai siklus 2 mengenai penggunaan model pembelajaran interaktif berbasisi aktivitas, dapat penulis simpulkan bahwa:

1. Dengan menggunakan Model pembelajaran interaktif Berbasis Aktivitas, ternyata mampu meningkatkan prestasi belajar siswa kelas VI SD Negeri 09 Kabawetan pada materi

2. Melalui Model pembelajaran interaktif Berbasis Aktivitas, siswa dapat lebih aktif dalam kegiatan belajar, terutama pada mata pelajaran PKN.

\section{SARAN DAN TINDAK LANJUT}

Berdasarkan kesimpulan diatas serta hasil perbaikan dan pembelajaran, agar kegiatan belajar mengajar PKN yang membahas mengenai" Nilai-nilai juang dalam perumusan pancasila" anak lebih aktif, kreatif dan memberikan hasil yang optimal bagi siswa. Maka ada beberapa saran yang dapat disampaikan sebagai berikut :

1. Dalam kegiatan pembelajaran PKN sebaiknya guru menggunakan model pembelajaran interaktif berbasis aktivitas, karena dengan model pembelajaran tersebut dapat meningkatkan prestasi belajar siswa.

2. Guru hendaknya menerapkan pembelajaran interaktif, terutama pada mata pelajaran PKN, karena dapat mengaktifkan siswa dalam pembelajaran

\section{DAFTAR PUSTAKA}

Harlen, (1992), Model Pembelajaran Interaktif. London: Kogon Page

Kusnan M. Rosyid,(2010). Pendidikan Kewarganegaraan Kelas VI. Jakarta: Intan Pariwara

Suciati,(2007). Belajar dan Pembelajaran 2. Jakarta: Universitas Terbuka

Sudjana,(1990). Prestasi Belajar. Jakarta: Rineka Cipta

Sukardi,(1983). Pedoman Penilaian. Jakarta : Rineka Cipta

Usman,(1999). Penerapan Model Pembelajaran Interaktif. Bandung: Pustaka Martina.

Winaputra, S Udin, (2005), Materi dan Pembelajaran. Jakarta : Universitas Terbuka

Winaputra ,S Udin, ( 2005), Strategi Belajar Mengajar. Jakarta : Universitas Terbuka

Wardani I.G.A.K, Wihardit Kuswaya, Nasution Noehi. ( 2006 ). Penelitian Tindakan Kelas (PTK). Jakarta : Universitas Terbuka 